\title{
The Practice of Extensive Reading among EFL Learners in Tertiary Level
}

\author{
Feny Martina, Syafryadin, Jeka Agustia Utama \\ IAIN Bengkulu, University of Bengkulu, IAIN Bengkulu
}

\begin{abstract}
Students had some problems in terms of extensive reading. The problems were (1) students forget some principles and benefits of extensive reading because they learned about principle and benefits of extensive reading in the previous semester, (2) students do not know how to implement a successful practice of extensive reading, and (3) students were still difficult to enjoy and get information in their reading of either fiction or nonfiction books. Thus, this research was aimed to know how students implement extensive reading and students' difficulties when practice extensive reading. This research was qualitative descriptive research. The subject of this research was the fourth-semester students in the English Education Study Program of Institut Agama Islam Negeri Bengkulu. The instruments of this research were observation checklist, interview sheet, and documentation. The result of this research showed that there were students who implemented extensive reading but students implemented extensive reading in the outside classroom and the students still had difficulties when implementing extensive reading. The percentage of students' implementation of extensive reading in the outside classroom was $62 \%$ while the percentage of students' difficulties encounter practicing extensive reading was $91 \%$. It concluded that students implemented extensive reading in the outside classroom without the supervision of the lecturer and students have many problems when practice extensive reading.
\end{abstract}

Keywords: Extensive Reading, EFL Learners

\section{Introduction}

The practice of extensive reading was not popular enough in Indonesia, in the curriculum does not mention anything explicitly about extensive reading. The document did not mention explicitly about the characteristics and the method of practicing extensive reading in the classroom environment. Thus, the principles of extensive reading in the EFL tertiary level were not implemented as the way it should be. Meanwhile, there have been so many studies and experts said that extensive reading was very important in teaching and learning EFL learners because extensive reading is one of the approaches that aimed to use reading as a pleasure, thus, students will enjoy reading (Day \& Bamford,2003). Besides, extensive reading is a useful activity for students and teachers to improve students' ability in reading (Salameh, 2017)

The results of some research showed that extensive reading can improve students' English skills. The first, a report by (Salameh, 2017) who investigated the impact of extensive reading by documenting it was positive effects on changes in different aspects of EFL reading attitudes, and the results reveal extensive reading can improve students' reading speed, writing skill, and increase students motivation in learning EFL (Salameh, 2017). In other words, extensive 
reading indirectly influences students' habits and attitudes toward English skills. Extensive reading also can develop general world knowledge (Salameh, 2017). Students have rather limited experience and knowledge of the world they inhabit both cognitively and affectively (Sari, et al., 2020). Extensive reading opens a window on the world seen through different eyes. So extensive reading extends, consolidates, and sustains vocabulary growth.

However, the function of extensive reading cannot be emphasized enough among EFL learners. Extensive Reading was very rarely used in the teaching-learning process. The key issue was how to adapt the extensive reading approach to students' attitudes, interests, abilities, and goals. Students were usually busy people and claim that they may not have much time for reading (Hermanudin, et al., 2019). This also happened to EFL learners at Institut Agama Islam Negeri Bengkulu, in the teaching and learning process, the students were very rarely used extensive reading (Alavi, et al. 2017). This was evidenced by observations with students. Students said that extensive reading was a new approach, and being new, it was difficult to implement. The students do not know the benefits, principles of extensive reading, and how to implement extensive reading. The lack of information was often a precursor to the misconception about extensive reading. Therefore, extensive reading is essential to be implemented because if students do not do extensive reading, students will not make themselves enjoy the reading itself. Consequently, it will decrease their motivation in reading and have an effect on other language skills, such as speaking, listening, and writing because reading is receptive skills. If students had good receptive skills, it will have a good impact on their other language skills (Day \& Bamford,2003).

Based on the problems and previous studies, the researchers tried to investigate the implementation of extensive reading and find out the difficulties of the students when implementing extensive reading among EFL learners at tertiary level at Institut Agama Islam Negeri Bengkulu. So, researchers investigated the extensive reading practices among EFL students at the tertiary level.

\section{Methods}

This research applied a descriptive qualitative that aimed at providing description pertaining to the kind of data gathered and analyzed. Descriptive qualitative was a method to deeply observe the characteristics of the individual unit such as a person, a group or a community, in order to analyze various phenomena in relation to that unit of study (Arikunto, 2006; Bungin, 2007; Yusuf, 2014, Now, 2008)

The researchers focused on investigating the implementation of extensive reading among EFL learners at the tertiary level (in prose and poetry at the fourth-semester students of English Educational Program of 
Institut Agama Islam Negeri Bengkulu in academic year 2018/2019).In this research, the researcher tried to explore in detail the students' case of their attitudes toward extensive reading in their educational process in Prose and Poetry class through in-depth data collection.

This subject of research conducted to the fourth-semester students in English Education of Institut Agama Islam Negeri Bengkulu. The subjects were 30 students of class B for the fourthsemester in the prose and poetry class in the academic year 2018/2019. The students' age was about 19 and 20 years old. The class consisted of 13 male and 17 female students. The researchers decided to select this class because the students in the class followed an extensive reading approach as a part of the English foreign language program. In addition, the interviews of the students who taught the classes that the researchers observed were conducted to get their opinion and suggestion about the Implementation of extensive reading implementation among EFL learners in Tertiary Level.

To determine the research respondents, researchers used a snowball sampling technique. A sampling procedure may be defined as snowball sampling when the researchers access respondents through the contact information that is provided by other respondents. This process was, by necessity, repetitive: respondents refer the researchers to other respondents, who are contacted by the researchers and then refer her or him to yet other respondents, and so on. Snowball sampling was employed instrumentally, as a safety net or a fallback alternative, when other means of obtaining information (usually epidemiologic) was not feasible (Miles, et al. 2014). Thus, the researchers used a snowball sampling technique because this sampling technique is easy to implement, to help researchers to find out the correlation among the phenomenon, and to assist the researchers in answering research questions.

The researchers used observation and interviews in collecting the data. While the research instruments were tools which were used by the researchers to collect the required data. The researchers used Willy A. Rinandiya's theory for all of the statements students daily reading activities and students' difficulties when implementing extensive reading in the observation and interview (Renandya, 2007). Before researchers collected the data, the researchers permitted to the institution (IAIN Bengkulu) to conduct the research. After getting permission, researchers discussed the procedures of this research to the English lecturer there. Students and English lecturer agreed to be interviewed and observed during this research. The researchers interviewed participants after extensive reading class was over namely on November 21st and 22nd, 2019. While. Researchers did an observation during the class of extensive reading 
namely start from August 12th until the 20th of November, 2019. To check the validation of the instruments, researchers used expert judgment and member checks.

Next, the researchers used some techniques in data analysis for qualitative, researchers used theories from Miles and Huberman (Miles, et al. 2014). In general, Miles and Huberman assume that the analysis consists of three lines of activities that occur simultaneously, namely: data condensation, data display, and drawing and verifying conclusions (Miles, et al. 2014). The complete explanation as follows:

\section{a. Data Condensation}

Data condensation was defined as the selection process, focusing on simplification, abstracting, and transformation of "rough" data that emerges from written records in the field. As we know, the reduction of data, was ongoing as long as the qualitative-oriented project takes place. In the fact, even before the data is really concluded, the anticipation of the existence of data reduction seems to have occurred when the researchers decided (often without full awareness) of the conceptual framework of the research area, research problems, and short which data collection to choose. As long as the data collection takes place, there will be a further reduction stage (making a summary, coding, tracing the theme, making clusters, making partitions, writing memos). Data Condensation/processes continue after the field research until the final report is complete. In the conduct of research Miles and Huberman were convinced that better presentations were the main way for valid qualitative analysis (Miles, et al. 2014).

\section{b. Data Display}

The second important flow and analysis activity was data display. Miles and Huberman limit a "display" as a set of structured information that gives the possibility of drawing conclusions and taking action (Miles, et al. 2014). Various presentations that can be found in everyday life start from gasoline gauges, newspapers, to computer screens. By looking at the presentations we will be able to understand what is happening and what must be done further analyze or take action based on the understanding obtained and the presentations. Data display would provide the data gathered of this research from the interview and observation checklist.

\section{c. Drawing and Verifying Conclusions}

The third important analysis activity was drawing conclusions and verification. From the beginning of data collection, a qualitative analyzer began to look for the meaning of things, record order. Explanations, possible configurations, causal lines, and propositions. Competent researchers handled the conclusions loosely, remain open and skeptical, but conclusions have been provided, initially unclear, but by borrowing the terms chiasic and Glaser and Strauss state then increasing to more detailed and firmly rooted. "Final" conclusions 
may not appear until the data collection ends, depending on the size of the set of field notes, coding, storage, and retrieval methods used, the researchers' skills, and the demands of the donor, but often the conclusions have been formulated beforehand, even if a researcher claims to have continued "inductively".

\section{Results and Discussion}

\section{Results}

\section{a. A Brief Review of Prose and Poetry Class (Context of the Present Study)}

Prose and Poetry class was one of the subjects that apply great understanding in the extensive reading learning processes and increase the students' interest toward reading because in this subject students are required to read literary works such as the sonnet, poetry, short story, novel, and even drama script.

Teaching Prose and Poetry during a semester, it spent about 14 meetings included Mid-Test and Final Test. It was divided into two parts; meeting 1 till to meeting 7 is about theories, and meeting 8 is for Midterm. Then, 8 meetings after Mid-term for practice, it covers from meeting 9 to meeting 13, and the last meeting was for Final-test. In this lesson, the lecturer wants to make the students understand theories in prose and poetry before they practice it in reading the literary work. This lesson aimed at preparing students to understand how to read and analyze literary work. The students also get comprehension about base knowledge in the study of prose elements of fiction. The students were discussed to cover all the material because they study it very detail in this semester. In reading literary works, extensive reading was very important because students must be able to understand the text that they read and also able to interpret the text.

For the data need of the research, the researcher explored the syllabus of prose and poetry class. The details explanation for each point above can be described as follows:

1) Introducing and Explaining Literature in General

At the first meeting, the lecturer introduces and explains literature in general, the main subject of which is the introduction, course overview, work of literature at glance. In this first meeting, the subject matter of the discussion was about the general view of the lecture, the purpose of the lecture in English, and a glimpse of the world of literature. While the indicator of success in this first meeting is understanding literature in general. The lecturer explained that the learning methods in Prose and Poetry class are three parts, namely: (1) group discussion. In this section, students will discuss each material that has been shared with each group at the beginning of the meeting.

They discussed the material with a guide to the existing syllabus; (2) questions and answers between students. in this section is the opportunity to ask questions after the discussion session is finished, the 
students will ask questions to the group that presents the paper and then the speaker will answer the questions that have been given previously; (3) explanation of lesson and correction. In this section, it is the turn of the lecturer to give an explanation of the material that has been discussed by the student who presented the paper, and at this session, the lecturer will also provide corrections to the material discussed until the paper that has been made to be improved for the next meeting. So at this meeting students only knew about literature in general because the lecturer had not explained it in depth.

\section{2) Explain About Literary Works} (Fiction and Non-Fiction)

The second meeting of the material discussed the form and structure of literary works (fiction and non-fiction). At this meeting explained by each group about the theory, the types of works of fiction and non-fiction, and its elements. The indicator of success at this meeting is that students can understand the material and be able to distinguish between fiction and non-fiction and understand the elements.

The students will present the material according to the source given by the lecturer, then, at the end of the meeting, the lecturer will give a detailed explanation again so that students are more aware of the material discussed by the group that presentation that day. This is intended so that students have prior basic knowledge of the material to be discussed so that they will more easily understand. So before students implement extensive reading, they must understand the theory, the types of fiction and non-fiction works and their elements, the goal is that students understand what they read and can increase the level of understanding of meaning in reading.

3) The Elements of Fiction

At the third and fourth meetings discussed the intrinsic elements of fiction. The material at this meeting is a point of view, theme, plot, setting, character, and style. The aim of this learning is for students to be able to identify elements in a short story. Students learn about how to determine and analyze points of view, themes, plots, settings, character, and styles so that they can determine the points of view, themes, plots, settings, characters, and styles of students having to do deep understanding. So at this meeting students have been introduced to reading material for extensive reading practices, namely short stories, students have been given basic material that they must obtain after reading.

4) Reading

At this meeting, students practice reading, analyzing, and understanding literary works. The lecturer uses the Student-centered learning approach, which in the student learning process is at the center of the learning process. In this approach, students are expected to be active and independent participants in the learning process. In the extensive reading practice the lecturer 
assigns students the opportunity to read short stories, the lecturer gives freedom to students to read at home or read in class. As for reading material, the lecturer gave the material to be read, so students have been provided with material to be read and analyzed.

The material provided by the lecturer is in accordance with students' abilities, and the material chosen is an interesting material. The lecturers prepared some short stories, especially the famous short story. In this extensive reading practice, the material read by students is a short story entitled "The Killers by Ernest Hemingway". The indicator of the success of this meeting is that students are able to understand the material provided (short story) and are able to find the elements and appreciate the literature. It means the lecturer had applied extensive reading in teaching Prose and Poetry because it has the same idea as Harmer's idea. He said that in learning extensive reading, the teacher should use specially written materials especially simplifications of established works of literature. A short story is one kind of literary genre that the reader needed to have interpretation skills to read it [15].

\section{5) Mid-Term}

This meeting assessment was Mid-Term. The lecturer took the main assessment from Mid-Test, in this assessing the lecturer gave the students some objects to analyze and asked them to prepare for a long time before the test. The students should make a paper about their analysis of the object of literary work, in this case, was a novel. They should read and interpret the novel after that made their analysis in their group paper.

The students read novels chosen by themselves and each group reads different novels. Each student reads the novel they have chosen in each group, they are also free to read in class or outside the classroom, with their own reading styles. After each student reads the novel, they discuss the analysis of intrinsic elements of fiction that they must make. After that, they made a paper and gathered it to the lecturer.

So at Mid-Term students practice extensive reading, which they are free to determine the material they read and according to their abilities and interesting novels. Students are also free to determine their reading style which can make them not tired of reading and can analyze the novel.

6) Prose

At the eighth meeting discussed the form of structure and intrinsic non-fiction elements. It has been explained previously that the lecturer uses the Student-Centered Learning approach, so students are given the task of making papers about the shape of structures and intrinsic non-fiction elements after they are presented in front of the class. Students are required to understand the material and be able to recognize the elements associated with nonfiction literature. The presentation group is also tasked with reading one process and analyzing the structure and intrinsic non-fiction elements so 
that they can explain and provide examples to other students. After the presentation group finished the presentation, a question and answer session was opened, the other students were free to ask about material that was not yet understood. After that, the lecturer gives a deep explanation to increase students' understanding.

So at this meeting students practice extensive reading because the presentation group was tasked with analyzing the Process and conveying the results to other students. Students implementing extensive reading at home because the lecturer provides homework to students to read, analyze, interpreted, and evaluated the literary works (process). Reading material was searching and chosen by students.

\section{7) Poetry}

The 9th meeting discussed the structure and intrinsic elements in Poetry. Students must understand the material and be able to analyze the elements related to non-fiction literature. The presentation group must understand the material indepth so that they can analyze and deliver the results of the analysis in front of the class. The reading material was poetry, poetry selected, and determined by the students themselves, which is in accordance with the students' abilities. The learning system at this meeting was still the same as the previous meeting, namely discussion.
8) Analyzing and Appreciating Literary Works

After they read the process or poetry they have chosen, they discuss it and analyze and appreciate the literary work they have read. Students make papers and present them in front of the class. Students must be able to convey the results of their analysis in a structured manner in front of the class because after students present, the lecturer will check their paper and give criticism about the results of student analysis, then review and conclude the results of the discussion and conduct evaluations and follow-ups.

9) Wrap-up and Final Task

At meetings of thirteen students and lecturers review literary theories and their elements (fiction and non-fiction). At this meeting, students and lecturers discuss the past material. The lecturer conducts a review aiming for students to understand the material discussed during the 1 semester of the teaching and learning process in the classroom. In this meeting, students will also be given the final assignment by the lecturer, where this final assignment will be given individually. The final task given to students is analyzing literature. The novel prepared by the lecturer is "Crazy Sunday and That Evening Sun Go Down". Students will practice reading the novel again and analyze the novel individually.

10) Final-Term

The last meeting is Final-Term, for the final-term lecturer the task is 
for students to jump directly into the field to gather old (traditional) prose in Bengkulu Province. Students are divided into groups and each group determines the place they will go. In this field learning students will meet the community and gather old (traditional) prose. After all, was collected, students conducted an analysis of the old prose. And the old prose they have collected will be made into a book at the end of the semester. To make a book, of course, students must understand the material they will discuss, namely the old prose that they get from the community. Students must read extensively to capture the core of the reading they are reading. Students must change their language from the old prose because the old prose still uses regional language.

\section{b. Students Daily Reading Activities in Implementing Extensive Reading}

To know about extensive reading practices in prose and poetry class, it was important to follow teaching-learning activities in Prose and Poetry class and students' activities in the outside classroom. The researchers have followed some meetings to checked about the implementation of extensive reading in Prose and Poetry class. In getting the data of this research, the researchers used the observation checklist consists of 8 statements about students' daily reading activities adopted from Willy Renandia's theory (Miles, et al. 2014). The researchers observed in every meeting of the class to know about their activities, then make some marks in the observation checklist. Then, the researchers describe the activities to get information to fulfill the data of the research. These were the eight statements about students daily reading activities of extensive reading that the researcher's observation in the prose and poetry class:

1) Students Implement Extensive Reading in the Classroom

In the classroom, students implement extensive reading, after the lecturer in Prose and Poetry class introduces students about base material of extensive reading before teaching them how to interpret literary work. The researchers found that the learning process carried out by students at each meeting showed that extensive reading was not applied in student learning activities in the classroom. In the teachinglearning process in Prose and Poetry class, the lecturer applied a discussion system. For example; the students discussed the materials about Intrinsic Elements And Fictions Genders. There are eight Intrinsic Elements and Fiction Genders such as theme, plot, setting, character, point of view, Irony, symbols, and fiction genders. So before the student's discussion in the Prose and Poetry class, the students reading novels and try to analyze the novel to get eight Intrinsic Elements and Fictions Genders in their Home.

2) Students Implement Extensive Reading Just in the Prose and Poetry Class 
Students implement extensive reading just in the Prose and Poetry class because in another class the lecturer didn't implement extensive reading to increase students' ability. To know about extensive reading practices in another class, the researchers do observations in each subject except Prose and Poetry class.

3) Students Implement Extensive Reading in the Outside Classroom

The researchers do observation for students' daily activities in the outside classroom, researchers found that in the outside classroom students implement extensive reading. The students implement extensive reading at every week when lecturer give homework for students, and they must read some novel at their home and analyze the novel, they do the analytical assignments at home in the form of papers and will collect about a week later. After that, the students explain the result of their novel analysis in the class.

4) Students Implement Extensive Reading After the Lessons and Apply in Each Subject to Increase Their English Skills

After the lesson Prose and Poetry students implement extensive reading because basically when the lecturer gives a reading to be analyzed by students, they do the analytical assignments at home in the form of papers and will collect about a week later. However, students did not apply extensive reading in each subject because in another subject the lecturers did not use extensive reading to increase students' English skills.

5) Extensive Reading is a Normal Activity that Includes Students in the Community of First Language Users Rather than Being a Foreign Language Students consider extensive reading to be a normal activity, even though the reading material they read is not their first language. By reading material in a foreign language, students assume that extensive reading can help improve their English vocabulary. Therefore students are very interested in practicing extensive reading in their learning activities to improve their English skills. They said that extensive reading was a very good habit to improve understanding of the second language (English) because with Extensive practice reading students can improve all English skills such as vocabulary, grammar, reading speed, and writing proficiency [14].

6) Students Implement Extensive Reading Every Day

Students do not apply extensive reading every day, but only a few days a week. The prose and poetry class was only one meeting every week, and every week the assignment was given by the group lecturer. So those who were given the task of reading each week are alternating, the group that will be presenting at the next meeting was doing the extensive reading.

7) Students implement Extensive Reading in the Outside Classroom by 
Creating Their Own Reading Group

It was explained earlier that in the class prose and poetry students were divided into several groups, each week they were given material that they had to understand and given the task of analyzing literature, after which they made a paper and presented it to the class. It was certain that students read outside the classroom and make reading groups be able to make the paper which contains the analysis of literature as a task given by the lecturer.

8) Extensive Reading has a Part of Curriculum

Extensive reading was a reading approach that was still rarely used, especially in Institut Agama Islam Negeri Bengkulu. The curriculum does not state that extensive reading activities must be applied to every subject. But in the Prose and Poetry class lecturer using extensive reading as a reading approach because in learning Prose and Poetry students were required to understand, analyze and appreciate a literary work, this was in accordance with the syllabus (see appendix 1 to see the syllabus). To understand, analyze and appreciate a literary work, students must read every literary work they will analyze, extensive reading can help students to complete the task because doing extensive reading students can improve students' understanding of the literary work they read.

From the explanation above, it can be concluded that prose and poetry class was one of the potential courses to apply the extensive reading to the practice section because in the course students are guided to read literary works independently. Students implementing extensive reading in the outside classroom. Students often implement reading extensively outside the class because the lecturer gives free reading assignments, not necessarily in the classroom, and according to each style. The practice of its activities, although most students in this class had not enjoyed reading in the classroom because in the class there were so many students and made students can not focus to read, so students rarely to apply extensive reading in the class. Students do not apply extensive reading in other subjects, only on prose and poetry courses because only prose and poetry use the extensive reading approach.

\section{c. Students Difficulties When} Practicing Extensive Reading

In this part, the researchers used an observation checklist and interview to know about students' difficulties encounter of practicing extensive reading in Prose and Poetry class. The observation checklist used by the researchers to know about students' difficulties when implementing extensive reading in prose and poetry class, and then the interview used to make accuracy the result from the observation checklist. The observation checklist was consists of 9 statements. The interview was about 10 questions that conducted with 3 students from prose and poetry class in B class, they consist of 1 
student who was high achiever; 1 student was moderate achiever students; then 1 student was low achiever students.

The data below showed the result of the observation checklist and interview about students' difficulties encounter of practicing extensive reading in prose and poetry class:

\section{1) The Result From Observation Checklist}

a) Reading Independently is Difficult for Students

Based on the data above, students implement extensive reading in the outside classroom without the supervision of the lecturer. The materials gave by the lecturer to students, so students can not choose materials by themselves. Students felt very difficult when implementing extensive reading in the outside classroom and without lecturer. Students were very lazy to read the materials because they have no motivation to read and nobody guides them while reading.

b) Students Have No Time for Extra Reading

Students were very busy because they have many activities on the campus and in their homes. So to implement extensive reading every day, they have little time, they implement extensive reading just in the prose and poetry class, and when the lecturer gives the task to read and analyze the novel. They were difficult to divide their time to read and do other activities. c) Students Difficult to Find Suitable Reading Materials

Reading material greatly influenced the successful implementation of extensive reading. When reading materials interesting and suitable for students' ability so extensive reading will be successful. But in the prose and poetry class reading material choose by the lecturer, some students have no problem with the materials but other students have a problem with the material because the reading ability of students who still lack made it difficult for them to practice reading especially analyzing stories.

\section{d) Sleepy Students}

It means that when students implement extensive reading, students usually felt bored and did not interested to read. Students also can not focus on when implementing Extensive Reading maybe because they did not interesting in the materials. Sometimes students tired and students sleeping and they do not get information from the materials.

e) Smart Phones Have Killed Students' Ability to Focus on Anything for More Than Two Minutes

We know that Smartphones give bed influence on students reading activities. When implement extensive reading students must be focused, enjoy, and reading with pleasure. But so many students in prose and poetry classes still difficult to focus on when reading because of smartphones. Sometimes students open their phones and open their 
social media, they were very dependent on smartphone.

\section{2) The Result from Interview}

Researchers interviewed several students to get information about students' difficulties in practicing Extensive Reading. Firstly, researchers interview with students were high achiever. Base on the interview with Pega Mustika, she said that she just know several of principle and benefits of Extensive Reading and do not know how to make Extensive Reading practice successful because they learned about it in the previous semester so she forgot about it. In addition, she said that when implementing extensive reading they still have so many difficulties such as; when they practice Extensive Reading in the Prose and Poetry class they usually found some new vocabulary and they do not know what the meaning of the word; students do not have time to practice Extensive Reading because they have another course and have so many tasks from their lecturer, they only practice Extensive Reading in the Prose and Poetry class if the lecturer gave the task to read and analyze some novel every week.

Secondly, the researchers interviewed students were moderate achiever. Base on the interview with Ilham Rahmat, he said that they still have many difficulties when practicing Extensive Reading. First, they do not know about the principle of Extensive Reading because the lecturer did not explain the principle of Extensive Reading before they practice Extensive Reading in the Prose and Poetry Class. Students learned about the principle of Extensive Reading in the previous semester, so they forgot about it. Second, they only know a few things about the benefits of Extensive Reading. Third, he said he does not know how to make Extensive Reading successful, so students in Prose and Poetry class still difficult to practice Extensive Reading in the outside classroom because they do not know how to make it. They never learned and read the theory about how to make successful practice Extensive Reading. Fourth, when students implement Extensive Reading for example when they read literary work, such as novels, they usually found unfamiliar words, and they not interested to continue reading the novel.

$\begin{array}{ccc}\text { The last, } & \text { researchers } \\ \text { interviewed students with low }\end{array}$ achiever. According to Seli Sarah, she said that she does not know the principle, benefits, and how to make Extensive Reading practice successful. She also said that

when implement Extensive Reading in the classroom and outside classroom she have so many difficulties, such as; when implement Extensive Reading in the classroom, she think in the classroom so noisy because there are 34 students in the Prose and Poetry class, so she cannot focus to read; when implementing Extensive Reading in the outside classroom she said that she have difficulties such as smart phones can disturb her to reading, usually she 
open her Phone and open her social media, sometimes she felt bored to read and after that she sleeping, and she very lazy to read because the lecturer did not supervise or students feel they have not been too able to become independent learners when they have to read alone without guidance from lecturers in this course; for the materials, she said that the materials still difficult for her because she still found so many unfamiliar words, the reading level was still too high for her, she felt the material unsuitable with her ability, they were still difficult to enjoy and get information in their reading of either fiction or non-fiction books so, it made students are still troubled in enjoy their reading

Based on the interview, it can be concluded that the fourth-semester students of the English Education Program of Institut Agama Islam Negeri Bengkulu in the academic year 2018/2019 have not been understood about the concept of extensive reading that applied by a lecturer in prose and poetry class. Even though there were still a number of students who were still having difficulty in reading and analyzing literary works. So, overall they got many difficulties when implementing extensive reading in the classroom or outside the classroom.

It means that they have a problem when implementing extensive reading in prose and poetry class. d. Investigating the Solution for Teaching and Learning Process in the Prose and Poetry Class

The researcherss can conclude several solutions to overcome student difficulties in extensive reading practice in the prose and poetry class, as follows:

1) Before implement extensive reading students must know about theory of extensive reading, such as, principle, benefits and how to make extensive reading successful. The lecturer must explain theory about Extensive Reading before students read and analyze literary work.

2) Students read the materials must be freedom of choice means that students were select texts they expect to understand, to enjoy or to learn from.

3) The reading material must interest, close with their world and suitable with their abilities.

4) Extensive reading was silent, so when students implement extensive reading the lecturer must make the classroom to be a silent situation in order to understand the reading well.

5) When students implement extensive reading in outside classroom, students must make group reading and make schedule to reading a book or literary work, because if students did not make reading schedule, students will be lazy to read. All of students must read literary work when the lecturer give task to read and analysis literary work, do not just one or two students in the group 
reading literary work.

6) Smartphone could disturb the students' concentration. when implementing Extensive Reading inside and outside classroom, thus Smartphone must be turned off or silent mode during extensive reading was applied by students. This was based on the fact in the field that students were chatting with their friends, and opening social media during the class.

7) If the students reading a books or literary work and find unfamiliar words, students must continue reading without search the meaning of the word in the dictionary but mark it and search the meaning after finished reading a book or literary work.

\section{Discussion}

In this part, the researchers described each part of the analysis above. The research results were divided into two topics: students daily reading activities in implementing extensive reading and students' difficulties in practicing extensive reading. The two points were described as follows:

a. Students Daily Reading Activities in Implementing Extensive Reading

The researchers described students' daily reading activities in implementing extensive reading. In prose and poetry class, extensive reading applied in the teaching and learning process from beginning until the end of the material, both in the process of group discussion (theory) and also in the practice of reading the literary works. The students in the prose and poetry class implemented extensive reading in the outside classroom, they implemented extensive reading in the outside classroom when the lecturer gave tasks to read some poetry and analyze the poetry. The students implemented extensive reading in the outside classroom (in their home) when the lecturer gave the task to read some novels and analyze the novel, after that they made a paper and the result will be discussed by students in the next week. Students implemented extensive reading every week because their lecturer gave a task to read and analyze some novels in their home, especially in the prose and poetry class.

In reading novels and poetry, students were very enthusiastic because novels and poetry that are read have beautiful language and contain life values such as social values, educational values, and the value of hard work. Novels and poetry that have beautiful language and have social values will have an impact on the enthusiasm and motivation of readers in completing reading activities (Syafryadin, et al. 2020; Noermanzah, et al., 2020; Willy, 2017; Puspitasari, 2020; Wibowo, et al., 2020; Johirman, 2016). With novels and poetry reading activities, students' extensive reading skills gradually increase. 


\section{Conclusions}

Based on the analysis conducted by the researchers above, the researchers concluded that, prose and poetry class was one of the subject in Institut Agama Islam Negeri Bengkulu that applied extensive reading in their teaching learning activities. In this subject, some students already known the basic concepts of extensive reading well; and students were also able to applied extensive reading concepts in reading literary works because they had studied extensive reading even though it was only the basis for intermediate and advance reading in the previous semester, but there were few number of students was forgot about the theory of extensive reading. Nevertheless, there were few number of students (low achiever students) who still had difficulties in following the extensive reading practice, they consider level of reading material or material that given was too difficult for them, so they had a little difficulty in the process of reading and analyzing literary works provided by the lecturer.

In conclusion, the fourth semester students of prose and poetry class, especially in class B of English Education Study Program of Institut Agama Islam Negeri Bengkulu in academic year 2018/2019 already had still lack basic knowledge because they learned about concept of extensive reading in the previous semester and their students did not explain again about it. But students was familiar with extensive reading and applied extensive reading in their reading practice, then, the students in this class had some difficulties when they implemented extensive reading. Although there were some students had not been able to enjoy the reading. After the researcherss have searched more deeply, it turns out that these students were indeed classified as low achiever students, then, when in technically, the lecturer gave a few short stories to read but they still have difficulties because they thought that the level of reading material given was too high for them, this is also because in one class, the level of students' reading skill was different. In teaching and learning process in the prose and poetry class students must enjoy with reading, if they had not been able to enjoy their reading, they can be stressed and did not get the goals of reading.

\section{References}

Alavi, S., M., Kuriniawan, L.L., \& Rivadeniera, G. (2012). Approaches to Implementing Extensive Reading under Difficult Circumstances: ERWC1 Scholarship Recipients. Extensive Reading World Congress Proceedings, 1, 2012, p.15-18.

Arikunto, S. (2006). Prosedur Penelitian: Suatu Pendekatan Praktek. Jakarta: PT.Rineka Cipta.

Bungin, B. (2007). Penelitian Kualitatif (2nd ed.). Jakarta: Prenada Media Group.

Day, R.R. \& Bamford, J. (2003). Extensive Reading Activities for Teaching Language. Cambridge: University Press.

Harmer, J. (2003). The Practical of English Language Teaching (3rded.). USA: Longman.

Hermanudin, Suhartono, Suryadi, 
Noermanzah. (2019). Improvement of Reading Comprehension Ability by Using Core Models of Class VII a Students of SMP Negeri 10 Bengkulu Tengah. International Journal of Scientific and Technology Research, $8(12)$.

Johirman, J. (2016). Meningkatkan Kecepatan Efektif Membaca (KEM) dengan Menggunakan Metode Klos Siswa Kelas XI IPA 2 SMA NEGERI 6 Bengkulu Selatan. Diksa : Pendidikan Bahasa dan Sastra Indonesia, 2(1), 2232. doi:10.33369/diksa.v2i1.3223

Miles, M.B., Huberman, A.M., \& Saldana, J. (2014). Qualitative Data Analysis: A Methods Sourcebook, Edition 3. USA: Sage Publishing.

Noermanzah., Syafryadin., Sari, I.K., Martina, F. (2020). Narrative style of time Habiburrahman EL Shirazy in building the Bidadari Bermata Bening Novel. International Journal Psychosocial Rehabilitation. 24(10), 2141-2153

Now, C. (2008). Sampling Knowledge: The Hermeneutics of Snowball Sampling in Qualitative Research. International Journal Social Research Methodology, 11(4), 327-344.

Observation of students at the fourth semester at Institut Agama Islam Negeri Bengkulu, (February 10, 2019).

Puspitasari, E. (2020). Mind Mapping in CLIL: How It Facilitates Students' Reading Comprehension. Journal of English Education and Teaching, 4(2), 154-169.

Renandya, W. A. (2007). The Power of Extensive Reading. RELC Journal, $38(2)$, 133-149. doi:10.1177/0033688207079578

Salameh, A.M.L. (2017). Investigating the Effect of Extensive Reading on EFL
Learners': Reading Attitudes at Hail University in KSA. Journal of Education and Practice, 8(8), 7-13.

Sari, M.H., Susetyo, Noermanzah, Wardhana, D.E.C, \& Kusumaningsih, D. (2020). Understanding the Level of Students' Reading Comprehension Ability. Universal Journal of Educational Research, 8(5).

Syafryadin, Wardhana, D.E.C., Apriani, E., Noermanzah. (2020). Maxim Variation, Conventional and Particularized Implicature on Students' Conversation. International Journal of Scientific and Technology Research, 9(2).

Uden. (2013). The Extensive Reading Foundation's Guide to Extensive Reading. ELT Journal, 67(2), 270. https://academic.oup.com/eltj/article ட67/2/270/532187

Wang, Y.H. (2013). Incidental Vocabulary Learning through Extensive Reading: A Case of Lower-Level EFL Taiwanese Learners. The Journal of Asia TEFL, 10(3), 59-80.

Willy, A.R. (2017). Current Practice of Extensive Reading in Asia. The Reading Matrix: An International Online Journal, 17(1), 4849.doi:10.33369/jeet.4.2.154-169

Wibowo, Y., Syafrizal, S., \& Syafryadin, S. (2020). An Analysis of English Teachers' Strategies in Teaching Reading Comprehension. JALL (Journal of Applied Linguistics and Literacy), 4(1), 20-27. Retrieved from https://jurnal.unigal.ac.id/index.php/ jall/article/view $/ 3153$

Yusuf, M. (2014). Metode Penelitian: Kuantitatif, Kualitatif dan Penelitian Gabungan. Jakarta: Kencana. 